\title{
Erratum to: Isolation and characterization of 26 polymorphic microsatellite loci in golden mahseer, Tor putitora (Teleostei, Cyprinidae) and their cross-species amplification in four related species
}

\author{
Dhirendra P. Singh $\cdot$ W. S. Lakra $\cdot$ M. Goswami • \\ A. Gopalakrishnan • U. K. Chauhan
}

Published online: 7 May 2011

(C) Springer Science+Business Media B.V. 2011

\section{Erratum to: Conservation Genet Resour (2011) 3:141-145}

DOI 10.1007/s12686-010-9309-z

This paper has been retracted on the combined grounds of disputed authorship and inaccurate data. An investigation by the National Bureau of Fish Genetics Research confirms that the work was conceptualized by another researcher not included as co-author, while investigation by the journal reveals systematic errors (higher number of repeats) reported in 10 loci of the 26 submitted to NBCI and published in the paper. Dr A. Gopalakrishnan has withdrawn authorship from the paper. D. P. Singh has assumed the role of corresponding author from W. S. Lakra.

D. P. Singh's e-mail address is: dhirendraapratap@ gmail.com.

The online version of the original article can be found under doi:10.1007/s12686-010-9309-z.

\footnotetext{
D. P. Singh · W. S. Lakra $(\bowtie) \cdot$ M. Goswami ·

A. Gopalakrishnan

National Bureau of Fish Genetic Resources, Canal Ring Road,

Dilkusha, Lucknow 226 002, India

e-mail:wslakra@gmail.com

U. K. Chauhan

Awadhesh Pratap Singh University, Rewa, Madhya Pradesh,

India
} 